\title{
Flood and Drought Resilience Measurement at Andir Urban Village, Indonesia
}

\author{
Arief Sudradjat ${ }^{1,2, *}$, Anindrya Nastiti ${ }^{1,2}$, Kevin Barlian ${ }^{1}$, and Made Sandhyana Angga ${ }^{1}$ \\ ${ }^{1}$ Research Center for Infrastructure and Regional Development, Institut Teknologi Bandung, Bandung, 40132, Indonesia \\ ${ }^{2}$ Faculty of Civil and Environmental Engineering, Institut Teknologi Bandung, Bandung, 40132, Indonesia
}

\begin{abstract}
Flooding and drought are two of the most common environmental problems in Andir Urban Village due to its location near a tributary of the Citarum River, its concave geographic structure, and excessive groundwater usage. Traditional approaches that focus on constructing water management structures cannot provide a sustainable solution to these persistent problems in Andir. Thus, increasing resilience in dealing with flooding and drought effectively from different aspects is important. This study uses the Flood Resilience Index (FRI) via several indicators divided into five aspects, i.e., natural, physical, economic, social, and institutional. The Drought Resilience Index (DRI) measures the reliability and vulnerability of clean water supply and demand for local residents. The flood resilience level of Andir Urban Village is low with an FRI of 2.69/5, while the drought resilience level of Andir Urban Village is very low with a DRI of only 2.565/10. The measurements of FRI and DRI in a developing country needs to be done carefully by developing local indicators that are unique and relevant to the country's setting.
\end{abstract}

\section{Introduction}

Floods and droughts are water-related disasters that claim lives and cause financial losses. In the United States, in 2005 , losses due to droughts, floods, and tropical storms were estimated at US\$250 billion and claimed 100,000 lives $[1,2]$. In Indonesia, total annual financial loss due to floods (IDR 11.29 trillion) and droughts (IDR 1.29 trillion) was estimated at IDR 12.58 trillion and claimed 55 lives in the last decade [3]. Therefore, it is important to support and develop efforts to reduce or even eliminate the effects of floods and droughts through structural and non-structural approaches; this includes increasing community and regional resilience. Resilience itself is one of the factors that are taken into account in measuring Water Security [4].

The factors that contribute the most in increasing the potential for flooding are high levels of urbanization, poor waste management and climate change [5]. Poor urban planning and urbanization management, as well as the loss of vegetation due to deforestation, will reduce the ability of the soil to absorb rainfall, thereby, drastically increasing the potential for flooding [6]. In addition, the use of groundwater as a source of clean water due to poor urban and infrastructure planning may cause land subsidence and ultimately increase the risk of flooding in flood prone areas.

In order to overcome the problems of flooding and drought, a unique approach is needed that combines the use of water infrastructure and active participation of the community and local stakeholders [7]. This is a shift in the rationale for hazards and risks management and the solutions to disasters; from approaches that are only technical in nature to approaches with an understanding of the relationship between the occurrence of disasters and aspects of human activities [8]. One solution to overcome flooding that is based on this point of view is to increase local resilience [9].

Walker et al. [10] have defined resilience as the ability of a system to absorb disturbances to a certain extent and still be able to function normally. Related to flooding, the concept of resilience can be interpreted as the ability of an area to absorb the effects of flooding at a certain level before damage or loss occurs [11]. In this study, drought resilience refers to the reliability and vulnerability of the factors of supply and demand for drinking water needs [12].

\section{Flood Resilience Index (FRI) and Drought Resilience Index (DRI)}

FRI is an approach used to measure the resilience level of an area to flooding that integrates the 5R concept in Flood Risk Management (FRM): Reflect, Relief, Resist, Response, and Recovery [11]. Reflect is an action focused on awareness and adaptive capacity building based on past flood events. Relief is a flood buffering element using existing infrastructure and urban functions, e.g., green open space, and land use control. Resist refers to actions that minimize damage/loss caused by a flood event. Response refers to the actions taken during a flood event, such as the warning system for the community to signal 
when to start evacuating. Meanwhile, recovery is a postflood action to return the ecosystem to its previous state. FRI consists of five dimensions: natural, physical, economic, social, and institutional. These dimensions are composed of indicators which subsequently result in an index that measures whether an area has a high or low level of resilience towards flood events. Batica et al. [11] has measured the FRI of five large cities, i.e., Nice (4.27/5), Hamburg (3.51/5), Beijing (3.45/5), Barcelona $(3.05 / 5)$, and Taipei $(2.48 / 5)$.

Meanwhile, DRI measures the level of resilience towards drought events by focusing on the reliability and vulnerability of water supply, represented by supply stress and supply diversity, and demand factors, represented by water use efficiency and demand diversity [12]. Supply stress shows the percentage of water supplies used in each hamlet in the study area, while supply diversity shows how many sources of clean water there are in each hamlet. Water use efficiency shows the water usage (measured in liter/day) for each hamlet, while demand diversity shows the variety of sectors provided with clean water.

At the moment, there is still limited evidence of the application of FRI and DRI in developing countries [13]. This paper aims to develop an FRI and DRI specific to the situation in developing countries, such as Indonesia. Andir Urban Village in Bandung, West Java, is selected as a case study because of its unique geographical characteristics of being partly flood-prone and partly dry. This research is expected to assess the solutions to future flooding and drought problems by looking at the application of policies and community approaches.

\section{Methods}

\section{Study area}

Andir is part of the Baleendah Sub-district, Bandung Regency, West Java, Indonesia. It has an area of $3.78 \mathrm{~km}^{2}$, a population of 36,674, and 13 hamlets (RW - Rukun Warga) [14]. Andir is a bowl-shaped area intersected by two rivers, the Citarum and Cisangkuy. This area was selected because parts of this area are prone to flooding. The Hamlets 6, 7, 9, and 13 especially are flood-prone because these areas are located in close proximity to the two rivers. Other parts, such as Hamlets 4, 11, and 12, are relatively flood-free as these areas are located far from the source of flooding and have higher topographies. This variation in elevation enables the authors in categorizing each hamlet into a flood prone or flood free area. The majority of the communities in Andir rely on groundwater as their primary source of clean water, except in Hamlets 5 and 12 where some people have access to the piped water network from the local water utility (PDAM).

\section{Household survey}

The indicators in FRI consist of five dimensions, including social and economic dimensions. In order to collect information on these two dimensions, a survey was conducted on 400 households in Andir with a confidence level of $95 \%$ and an error level at 5\%. The participants were selected through a non-probability quota sampling because they must meet specific criteria to be included in the survey, i.e., a minimum age of 18 and they must have a place to live [15]. The data is collected by spreading questionnaires that consist of six parts, i.e., the location where the respondent lives, personal data, and specific information on their place of living and the facilities available to the respondents; their source of clean water; the flooding in the area; and information about the respondent's preparedness for flooding. The data from the household survey is used to calculate the DRI and FRI. The data was obtained primarily through questionnaires, because of the lack of secondary data in the study area.

\section{FRI calculation}

To calculate the FRI, the indicators that will be used to obtain the index value were determined [16]. Each indicator was classified into the $5 \mathrm{R}$ concept and five dimensions (Table 1). Weights from 1 to 5 were assigned to each indicator based on its importance to flood resilience. This research uses the assumptions based on Batica's research [16] which are shown in Table 2 below. Afterward, it was determined whether a hamlet is a floodprone area based on the respondent's answers (Figure 1). Only Hamlets 4, 11, and 12 are flood free. If the hamlet is not a flood-prone area, a score of 5 was given for most of the indicators in that hamlet. If the hamlet is a flood-prone area, the FRI was calculated using the Averaged Weight Mean Index (AWMI) shown by Equation 1 below. $I$ shows the value of the $i$ indicator, $w$ is the weight of the indicator, and $n$ is the number of dimensions calculated in the research $(n=5)$.

$$
F R I=\frac{\sum_{i=1}^{n} I i x w i}{\Sigma_{1}^{n} w i}
$$

\section{DRI calculation}

To measure the DRI, qualitative and quantitative indicators were integrated in three important factors: supply, demand, and adaptation capacity. In this research, the adaptation capacity factor was excluded since there is no real application of conservation and augmentation of clean water in the study area according to an expert respondent. The DRI was first calculated by first assigning scores to the indicators. Clean water supply in DRI includes two indicators: supply stress and supply diversity. Supply stress represents a hamlet's distribution pattern of clean water sources in average liter/day, while supply diversity represents to what extent a hamlet has alternatives of clean water supply to meet water demand. This research assumed a score of 0 for supply diversity as the majority of the hamlets rely on groundwater, except for Hamlet 5 that is fully supplied and Hamlet 12, that is partly supplied by piped water service from the local water utility. Supply diversity is expressed by a GiniSimpson Index as a fraction from 0 to 1 .

The clean water demand factor includes two indicators: demand stress and water use. Demand stress shows the quantity of water use per day in a hamlet. 
Demand diversity shows the variety of clean water demand from different sectors in a hamlet, whether it be commercial, household, industrial, etc. Similar to supply diversity, demand diversity is expressed by a GiniSimpson Index as a fraction from 0 to 1 . This research

Table 1. Assumptions used for flood-prone hamlets

\begin{tabular}{|c|c|c|}
\hline $\begin{array}{c}\text { Indicator } \\
\text { Dimension }\end{array}$ & $\begin{array}{c}\text { FRM } \\
\text { Element }\end{array}$ & Indicators \\
\hline \multirow[t]{2}{*}{ Natural } & Relief & $\begin{array}{l}\text { Flood characteristics in each } \\
\text { hamlet in Andir }\end{array}$ \\
\hline & Relief & Green open space in Andir \\
\hline \multirow[t]{5}{*}{ Physical } & Resist & $\begin{array}{l}\text { The condition of the } \\
\text { embankment along the river }\end{array}$ \\
\hline & Resist & $\begin{array}{l}\text { The number of houses with } \\
\text { flood-proof construction }\end{array}$ \\
\hline & Resist & $\begin{array}{l}\text { The number of buildings with } \\
\text { optimally working drainage }\end{array}$ \\
\hline & Resist & $\begin{array}{l}\text { The number of houses with } \\
\text { clean water facility that is } \\
\text { accessible during a flood event }\end{array}$ \\
\hline & Resist & $\begin{array}{l}\text { The number of houses with } \\
\text { wastewater facility protected } \\
\text { during a flood event }\end{array}$ \\
\hline \multirow[t]{3}{*}{ Social } & Recovery & $\begin{array}{l}\text { The number of respondents } \\
\text { who get help during a flood } \\
\text { event }\end{array}$ \\
\hline & Response & $\begin{array}{l}\text { The number of respondents } \\
\text { who receive early warnings of } \\
\text { floods }\end{array}$ \\
\hline & Reflect & $\begin{array}{l}\text { The number of local residents } \\
\text { that participate in information } \\
\text { dissemination to increase the } \\
\text { awareness of floods }\end{array}$ \\
\hline Economic & Recovery & $\begin{array}{l}\text { The loss and negative impacts } \\
\text { experienced by the respondents } \\
\text { due to floods }\end{array}$ \\
\hline \multirow[t]{2}{*}{ Institutional } & Response & $\begin{array}{l}\text { The number of people } \\
\text { evacuated from the flooded } \\
\text { area }\end{array}$ \\
\hline & Recovery & $\begin{array}{l}\text { The ongoing program of river } \\
\text { conservation and cleanup }\end{array}$ \\
\hline
\end{tabular}

Table 2. Weights for indicators used in developing the FRI

\begin{tabular}{lc}
\hline \multicolumn{1}{c}{ Indicators } & Weight \\
\hline Nature & 5 \\
$\begin{array}{l}\text { Evacuation and flood warning, accessibility of } \\
\text { clean water facility }\end{array}$ & 4 \\
Urban land use and buildings protected from & 4 \\
flood & \\
Solid waste management, volunteers' actions & 2 \\
Other indicators & 3 \\
\hline
\end{tabular}

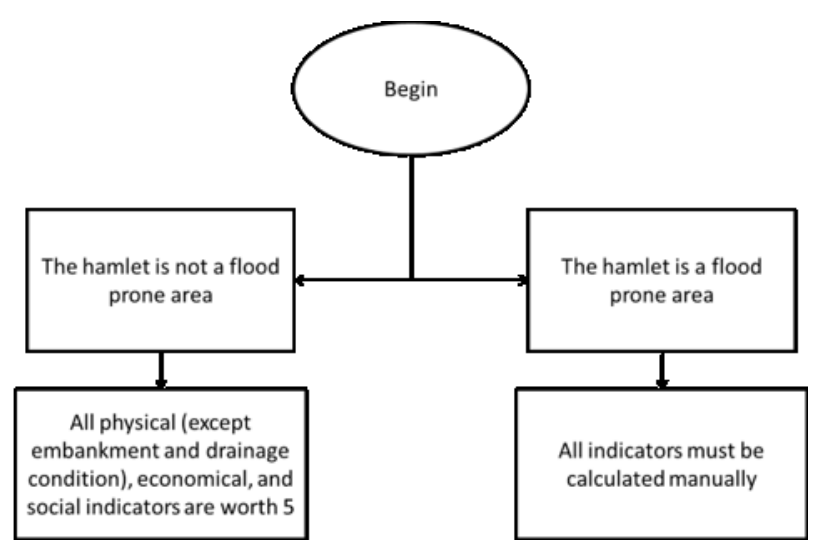

Figure 1. Assumptions used for flood-prone hamlets assumed a score of 0 for demand diversity as our target respondents are households.

All scores of the indicators were converted into an index value, ranging from 1 to 10, using Equation 2. $I$ is an indicator, $A$ is the low-end of the original value of an indicator, and $B$ is the high-end of the original value of an indicator. The supply factor was calculated with Equation 3 while the demand factor was calculated using Equation 4. The DRI was consequently calculated with Equation 5.

$$
\text { Re }- \text { scaled } I=1+(10-1) * \frac{(I-A)}{(B-A)}
$$

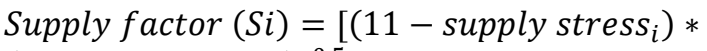
(supply diversity $)^{0.5}$

Demand factor $(\mathrm{Di})=\left[\left(11-\right.\right.$ demand stress $\left._{i}\right) *$
$\left(\right.$ demand diversity $\left.\left._{i}\right)\right]^{0.5}$

$$
\text { Local resilience }_{i}=[(S i) *(D i)]
$$

\section{Results}

\section{Determining the Flood Resilience Index (FRI)}

\section{Determining the FRI value for natural indicators}

Flood characteristics. The flood characteristics indicator is assessed through a number of sub-indicators that are in line with the Regulation of the Minister of Public Works Number 12 of 2014 on Urban Drainage Systems, i.e., the depth of inundation, flooding frequency, and duration for flooding to subside. Each sub-indicator has a range of values from 1 to 5 indicating how severe the flooding is in an area (see Table 3). The value for the flood characteristics indicator is the average for the total value of the sub-indicators. Table 4 provides information for the sub-indicator assessment. Andir Urban Village has an FRI for the flood characteristics indicator of 2.885 which indicates a low level of resilience. Three hamlets are free from flooding, i.e., Hamlets 4, 11, and 12, which, thus, have the maximum FRI of 5.

Green open space. The standards for the indicator of green open space are based on Law Number 26 of 2007 on Spatial Planning, which stipulates that the minimum area for green open space must be at least $30 \%$ of the total area of the city as a whole. Based on this limit, the standard median value for the FRI indicator is set at 30 percent of the green open space in Andir Urban Village (see Table 3). Based on the data obtained from [14], Andir Urban Village has 15 ha of paddy fields, followed by nonpaddy arable fields of 2 ha from the total area of 378.3 ha, thus, green open space makes up 4.5 percent of the total area. The FRI for the green open space indicator is 0.45 , which indicates a very low level of flood resilience.

\section{Determining the FRI value for physical indicators}

The physical indicators are viewed from the condition of embankments, the number of houses with flood-proof construction, the number of houses that have flood-proof 
access to clean water, and the number of houses that have flood-proof wastewater treatment systems.

Embankment conditions along the river. The standards for the indicator of embankment conditions are based on Regulation of the Minister of Public Works Number 8 of 2015 (PermenPU 8/2015) and the document of Embankment Engineering Planning by the Minister of Settlements and Regional Infrastructure Pd T-16-2004-A. Four sub-indicators are used, i.e., minimum freeboard height, the allocation of river setbacks, availability of inspection roads, and embankment building materials (see Table 3). The Citarum River has two embankments which can be accessed via Hamlet 13 and the Cisangkuy River which can be accessed through Hamlet 10. The survey has shown that the embankment conditions at both rivers are quite good and the sub-indicators of embankment building materials, minimum freeboard, and available inspection roads are met. The sub-indicator of the allocation of river setbacks has not been met because the area around the embankment has been used for residential buildings. The index for river embankment conditions is 4 which is a high level of resilience.

Houses with flood-proof construction. The standards for the physical construction of flood-proof houses are based on the document of the American Society of Civil Engineers (ASCE) 24-14 and City of Bandung Regulation Number 5 of 2010 (Perda Kota Bandung 5/2010). The sub-indicators are adapted to the wet floodproofing concept, i.e., the minimum ground floor height, the availability of an emergency clean water storage system in preparation for flooding, a good waste disposal system to prevent waterborne diseases, multi-story house design for emergency evacuation, and waterproof building materials (see Table 3). Andir Urban Village has a low flood resilience, with a value of 2.823 out of 5 . Hamlets 4, 11, 12 have the highest FRI value of 5 while Hamlet 3 has the lowest FRI value of 1.08.

Drainage conditions. The standards for the indicator of drainage conditions are based on Regulation of the Minister of Public Works Number 12 of 2014 (PermenPU 12/2014) on Urban Drainage Systems. Four subindicators are used, i.e., drainage is free from waste, drainage is free from sedimentation, drainage is waterproof, and the drainage system is separate from the household sewer system (see Table 3 ). The index value for drainage conditions in Andir Urban Village is 2.063, which indicates a low level of flood resilience. Hamlet 11 has the highest index of 4, while Hamlet 13 has the lowest index 0.84 .

Access to clean water during a flood event. The standards for the indicator of access to clean water that is protected from flooding are based on Presidential Regulation Number 59 of 2017 (PerPres 59/2017) on the implementation of the Sustainable Development Goals (SDGs), which stipulates that the baseline level of access to improved drinking water is $70 \%$ (in 2014). Based on this, the standard median value for the FRI indicator is determined at 70 percent of respondents have access to clean water during a flood event (see Table 3). Sixty-four percent of the respondents in Andir Urban Village have access to clean water during a flood event with an average index of 2.667, indicating a low level of resilience.
Hamlets 4, 11 and 12 have the highest index value of 5 . Meanwhile, the lowest index value is found in Hamlets 1 and 13 with an index of 0.4667 .

Household wastewater facilities that are protected during a flood event. The standard for the indicator of household wastewater treatment systems that are protected from flooding is also determined based on PerPres 59/2017, which stipulates that the baseline level of access to improved sanitation is $60.9 \%$ (in 2014). Based on this, the standard median value for the FRI indicator is set at 60 percent of houses in Andir Urban Village to have a household wastewater facility system that is protected during a flood event (see Table 3). The index for the indicator of household wastewater facilities that are protected from flood events is 3.5 , which indicates an average level of resilience. Hamlet 7 is the area that performs worst and experiences leakage of household wastewater where only 34 percent of respondents have a flood-proof wastewater facility with an index value of 1.7. Meanwhile, Hamlets 4, 11, and 12 have high levels of resilience because they do not experience flooding.

\section{Determining the FRI value for social indicators}

Social indicators are assessed from the equity of the distribution of flood assistance to residents, the effectiveness the flood warning system that is used by local residents, and the number of people that have been educated through information dissemination about the problem of flooding.

Distribution of help during a flood event to respondents. The standards for the social indicator of FRI of the distribution of help during a flood event was assessed by the number of respondents in a hamlet that received flood assistance (see Table 3 ). The index for the distribution of help during a flood event is 3.529 , which indicates an average level of flood resilience. Hamlet 5 has an index of 0 because less than 25 percent of respondents receive help during flood events. Hamlets 2 and 6 have an index of 5 because all respondents receive help during a flood event, while Hamlets 4, 11, and 12 also have an index of 5 because they are free from flooding.

Flood warning system. The standards for the indicator of flood warning systems are assessed by the number of respondents in a hamlet that receive early warnings of floods (see Table 3). The index for the early warning system for floods is 2.046 , which indicates a low degree of resilience. Three hamlets have an FRI of 5, i.e., Hamlets 4, 11, and 12 because they are flood-free. Hamlet 7 has an index of only 0.1 because it has only a few respondents who receive warnings about flooding.

Disseminating information on flooding. The standards for the indicator of the dissemination of information on flooding is assessed based on the number of respondents in a hamlet that join activities on disseminating information on flooding (see Table 3). The index for the dissemination of information on flooding is only 1.762 , which indicates a low degree of resilience. Three hamlets have index values of 5, i.e., Hamlets 4, 11, and 12 because they are free from flooding. Meanwhile, there are 3 Hamlets that have an index of 0 , i.e., Hamlets 7, 8, and 10 


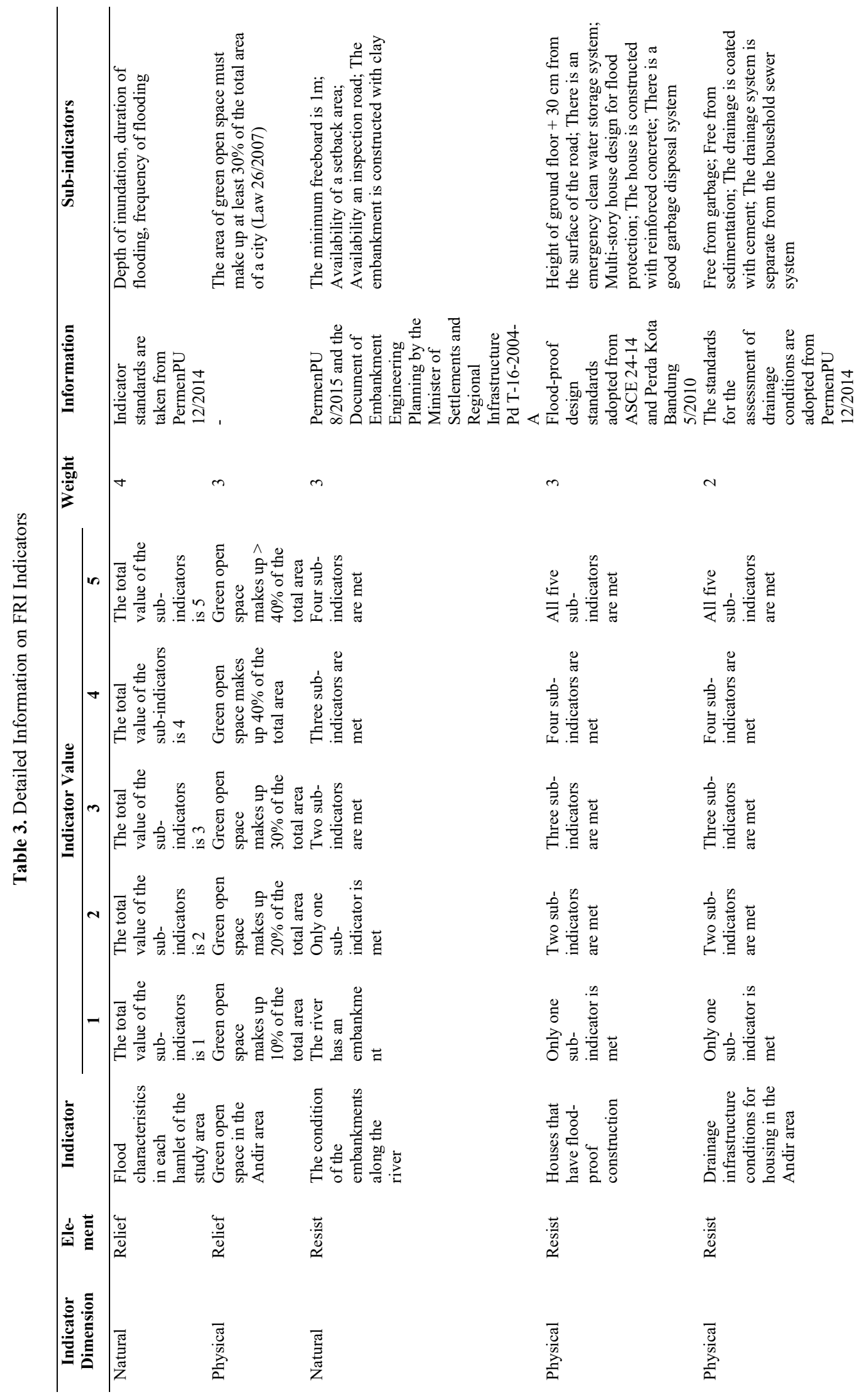




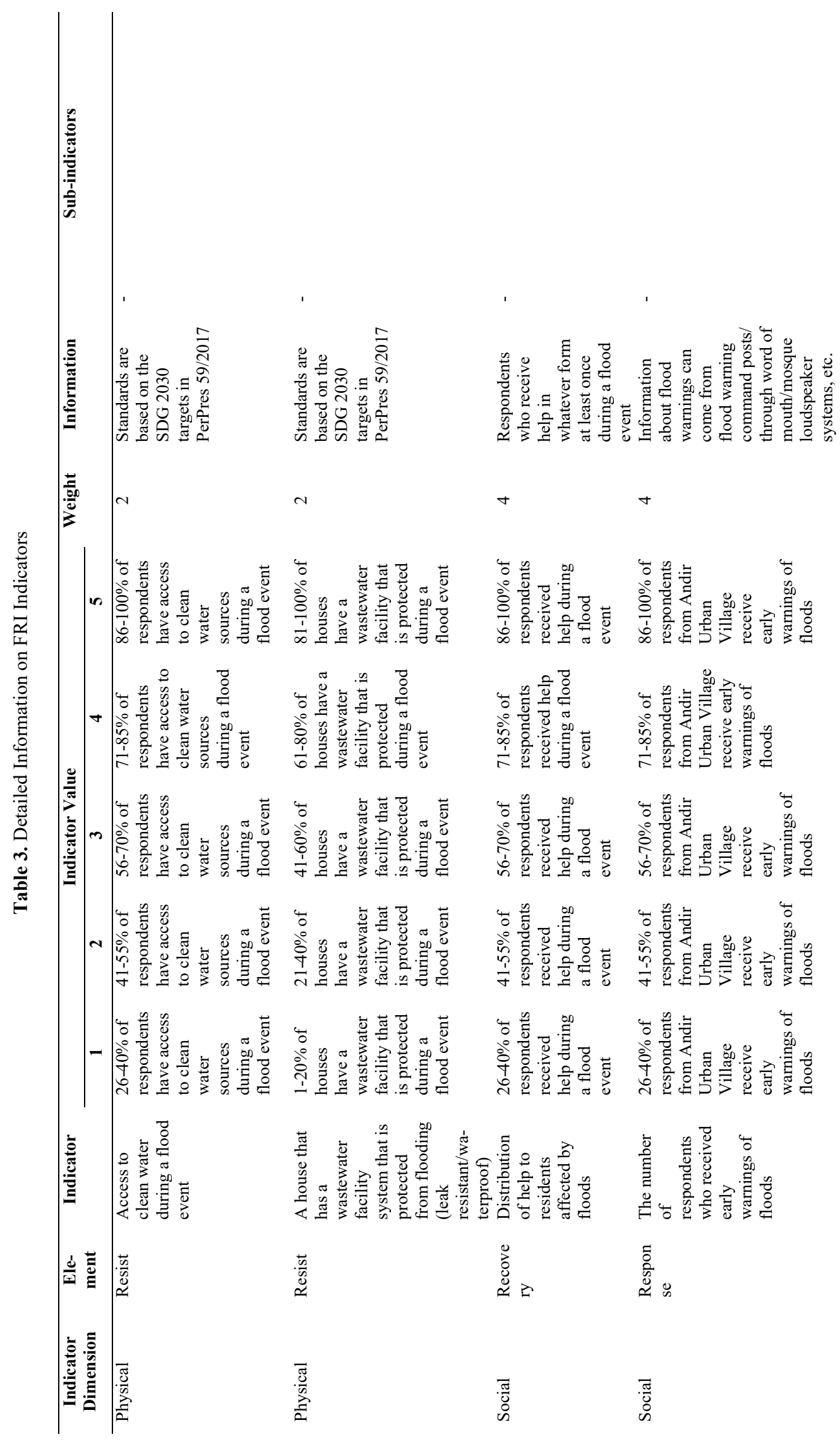




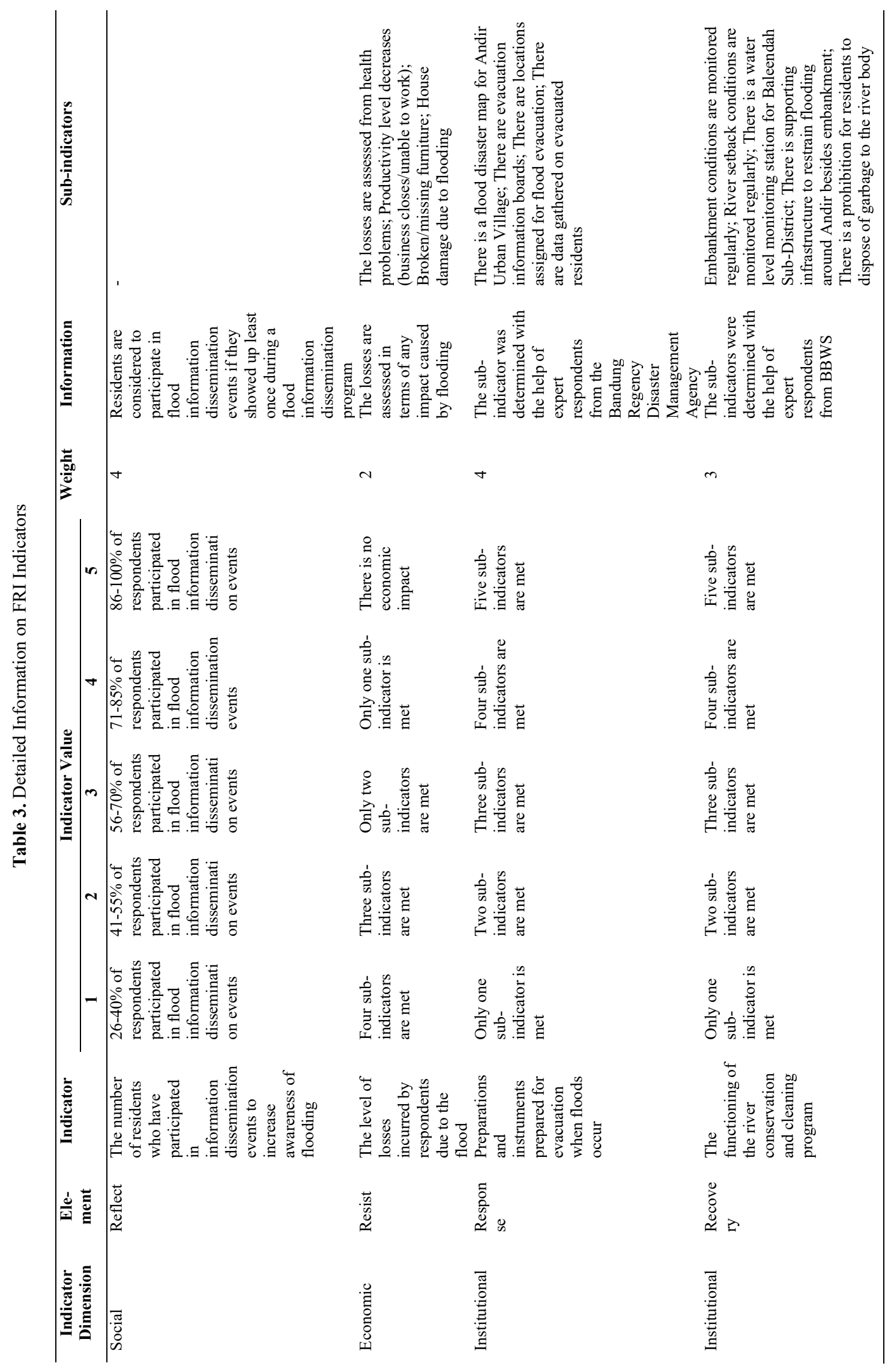


in which less than 25 percent of respondents have followed flood information dissemination activities.

Table 4. Sub-indicators for flood characteristics

\begin{tabular}{|c|c|c|c|c|c|}
\hline $\begin{array}{l}\text { Depth of } \\
\text { Inundation }\end{array}$ & $\begin{array}{l}\text { Sub- } \\
\text { indi- } \\
\text { cator } \\
\text { value }\end{array}$ & $\begin{array}{l}\text { Duration } \\
\text { of } \\
\text { flooding }\end{array}$ & $\begin{array}{l}\text { Sub- } \\
\text { indi- } \\
\text { cator } \\
\text { value }\end{array}$ & $\begin{array}{l}\text { Frequency } \\
\text { of flooding }\end{array}$ & $\begin{array}{l}\text { Sub- } \\
\text { indi- } \\
\text { cator } \\
\text { value }\end{array}$ \\
\hline$>100 \mathrm{~cm}$ & 1 & $\begin{array}{l}3-4 \\
\text { weeks }\end{array}$ & 1 & $\begin{array}{l}\text { Very often } \\
(>5 \\
\text { times/year) }\end{array}$ & 1 \\
\hline $76-100 \mathrm{~cm}$ & 2 & $\begin{array}{l}1-2 \\
\text { weeks }\end{array}$ & 2 & $\begin{array}{l}\text { Often (4 } \\
\text { times/year) }\end{array}$ & 2 \\
\hline $51-75 \mathrm{~cm}$ & 3 & 4-6 days & 3 & $\begin{array}{l}\text { Not so } \\
\text { often (3 } \\
\text { times/year) }\end{array}$ & 3 \\
\hline $26-50 \mathrm{~cm}$ & 4 & 1-3 days & 4 & $\begin{array}{l}\text { Rarely (2 } \\
\text { times/year) }\end{array}$ & 4 \\
\hline $0-25 \mathrm{~cm}$ & 5 & $\begin{array}{l}0-23 \\
\text { hours }\end{array}$ & 5 & $\begin{array}{l}\text { Very rarely } \\
(1 \\
\text { time/year })\end{array}$ & 5 \\
\hline
\end{tabular}

\section{Determining the FRI value for economic indicators}

The index for economic indicators is assessed in terms of any negative impact that residents experience during a flood event, ranging from illnesses caused by flooding, disruption of work activities, and material losses until house damage incurred (see Table 3 ). The value for the economic indicators is 2.791 which indicates a low level of resilience. Residents in two Hamlets are not negatively affected by flooding, i.e., Hamlets 4 and 11, thus, these hamlets have an index of 5 .

\section{Determining the $F R I$ value for institutional indicators}

The institutional indicators are assessed based on the readiness of relevant agencies/institutions in preparing evacuation plans and the effectiveness of the river conservation programs.

Evacuation plans for the residents of Andir. The value of the indicator of evacuation plans for the residents of Andir is determined by the readiness of the government in the form of the Bandung Regency Disaster Management Agency (BPBD) in preparing the residents of Andir Village to evacuate during floods. Five sub-indicators are used, i.e., the existence of a flood disaster map, instructions on flood evacuation locations, buildings for evacuation, data of the evacuated population, and an early warning system for floods (see Table 3). The survey showed that the sub-indicator of evacuation information boards and evacuation locations are met with the installation of information signs in Hamlets 6, 7, 9 and 13 (which are the most flood-prone areas) and a flood evacuation location in the INKANAS Building in Hamlet 10. Only the sub-indicator of the early warning system was not met because the water level monitoring tool in the Majalaya area has been broken since 2016. The index for the Andir resident's evacuation plan indicator is 4, which indicates a high level of flood resilience.

River conservation programs. The indicator of river conservation programs is assessed from the readiness of the government, in this case, the Citarum River Basin
Organization (BBWS) in maintaining and preserving river conditions at an optimal level. Five sub-indicators are used, i.e., there is a well-organized monitoring system for the condition of embankments and river setbacks, there are rainfall monitoring stations for the Citarum and Cisangkuy Rivers, there is supporting infrastructure in addition to embankments to deal with flooding, and there are prohibition instruments to prevent residents from disposing garbage in the river (see Table 3). Based on an interview with an expert respondent, there is no standard operating procedure for periodically monitoring the condition of embankments and river setbacks in the Andir region. However, embankment conditions and river setbacks are inspected at least once a year. BBWS has two water level monitoring stations for Andir Urban Village, i.e., the Dayeuh Kolot and Kamasan stations. However, the infrastructure for prohibiting garbage disposal is only available for the Citarum river. The flood mitigation infrastructure consists of retention ponds in Cienteung Village and the Cisangkuy floodway where its construction will commence in 2018. Two sub-indicators are met, i.e., the availability of water level monitoring stations and the infrastructure for the prohibition of garbage disposal into rivers, thus, the index value for river conservation programs is 2 , which indicates a low level of resilience.

\section{FRI of Andir Urban Village}

The Flood Resilience Index of Andir Urban Village is 2.69/5 which indicates a low level of flood resilience. Figure 2 shows the recapitulation of the index values of each indicator and the FRI for Andir Urban Village.

\section{Determining the Drought Resilience Index (DRI)}

The Drought Resilience Index will be determined by two factors, i.e., supply and demand. Table 5 shows a detailed description of the indicators and assumptions used to calculate each factor.

Supply stress and supply diversity. The supply stress factor shows the amount of water debit supplied to an area. The main source of water in Andir Urban Village is groundwater, therefore, we assumed that the amount of water used is uniformly distributed except in Hamlet 5 and Hamlet 12. Figure 3-top shows the allocation of water resources in all hamlets (RW). Meanwhile, the supply diversity factor shows how much water is available for an area. Almost all hamlets in Andir Urban Village use groundwater, except Hamlet 5 where all residents use piped water connections from the local water utility and Hamlet 12 where part of the residents have access to these piped water connections. Figure 3-bottom shows the GiniSimpson index for the supply diversity factor.

Water use and demand diversity. The factor of water use shows the average water use in an area. Residents in Hamlet 2 use the smallest amount of clean water with 4.140 liters/day, while the residents of Hamlet 1 and Hamlet 9 have the highest average water use of 7.680 and 7.620 liter/day respectively. Figure 4-top shows the recapitulation of the water use in each hamlet. Meanwhile, the factor of demand diversity shows the variety of sectors 
in need of water service. This study is focused on households and therefore, the demand diversity is constant at a value of 1 . Figure 4-bottom shows the recapitulation of the demand diversity in each hamlet.

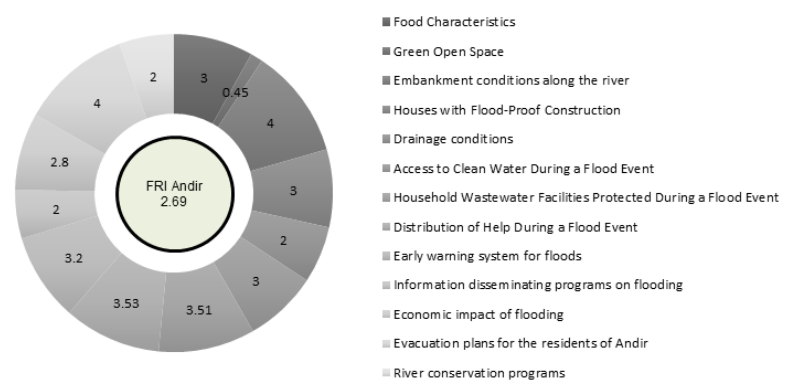

Figure 2. Recapitulation of index values for each FRI indicator

Table 5. Detailed information on the DRI indicators and assumptions in calculations

\begin{tabular}{clc}
\hline \multicolumn{1}{c}{ Factor } & \multicolumn{1}{c}{ Indicator } & \multicolumn{1}{c}{ Assumption } \\
\hline Supply & $\begin{array}{l}\text { Supply } \\
\text { stress }\end{array}$ & $\begin{array}{l}\text { The fraction of the main clean water } \\
\text { source's debit used by the residents } \\
\text { of Andir (groundwater flow) } \\
\text { Gini-Simpson Index: }\end{array}$ \\
$\begin{array}{l}\text { Supply } \\
\text { diversity }\end{array}$ & $1-\Sigma_{i}\left(\frac{\text { supply from source }}{\text { total supply }}\right)^{2}$ \\
Demand & Water use & $\begin{array}{l}\text { Average debit of clean water used } \\
\text { per day in the residential sector } \\
\text { Gini-Simpson Index: } \\
\text { diversity }\end{array}$ \\
& & $1-\Sigma_{i}\left(\frac{\text { demand from sector }}{\text { total demand }}\right)^{2}$ \\
\hline
\end{tabular}

\section{DRI of Andir Urban Village}

The DRI of Andir Urban Village is 2.565/10, which indicates a very low level of drought resilience. Hamlet 1 has the lowest resilience with an index of 1.742, while Hamlet 12 has the highest resilience with an index of 3.956. Hamlet 12 has high resilience because its residents have alternative sources of clean water from the piping network of the local water utility, PDAM Tirta Raharja. Figure 5 shows the recapitulation of the resilience index for each hamlet and the DRI of Andir Urban Village.

\section{Discussion}

The low Flood Resilience Index (FRI) value of 2.69 (out of 5) measured at Andir Urban Village shows the need to improve four FRI indicators, namely, green open space, information dissemination on flooding to the residents of Andir, drainage conditions, and river conservation programs, as soon as possible. The area of green open space can be increased by revitalizing the river setback area that the residents of Andir have converted into settlements. Stricter regulations are needed by clearing illegal settlements on the riverbanks and protecting the area from being converted into settlements again.

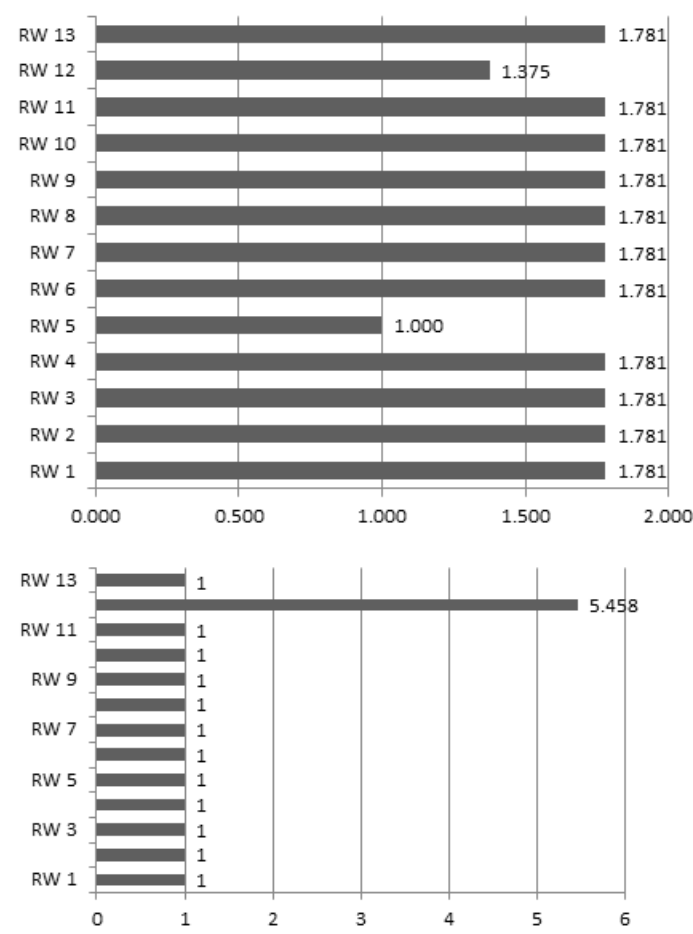

Figure 3. (Top) The allocation of clean water representing supply stress in in each hamlet in Andir Urban Village; (Bottom) The Gini-Simpson index for supply diversity

The low number of residents who are educated through flood awareness programs is caused by the lack of quality information dissemination programs that can educate residents about how to deal with flooding. The respondents of questionnaires provided feedback that the information dissemination program needs to provide residents with new information and practical knowledge that can be applied directly to face flooding rather than just distributing regular flood assistance. On the other hand, the low participation rate by residents in the study area in information disseminating activities on flooding indicates a lack of awareness about caring for the environment and seeking knowledge to find renewable solutions to overcome flooding.

The problem of drainage conditions requires an environmentally friendly approach, in the form of the Sustainable Urban Drainage Systems (SUDs) in the Cisangkuy-Citarum watershed. The first step in implementing this concept is to replace sidewalks with permeable pavement to increase the absorption capacity of water into the soil. Meanwhile, the institutional performance in conserving river basin conditions can be improved by developing clear SOPs and regular inspection schedules for river conservation programs.

The low Drought Resilience Index (DRI) of Andir is indicated by the limited sources of clean water, almost all of which come from groundwater. The uncontrolled use of groundwater causes the groundwater levels to decline and the groundwater supply to be depleted. This use of groundwater decreases the natural water supply which worsens the drought experienced in the study area. 


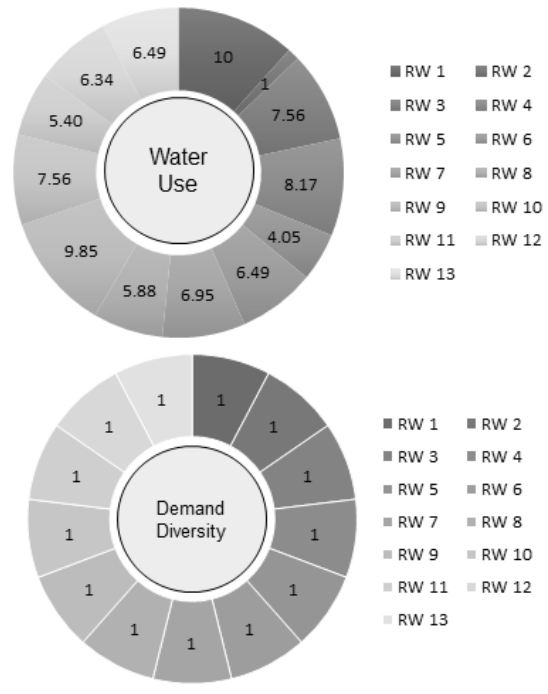

Figure 4. (Top) Recapitulation of the water use in each hamlet; (Bottom) Recapitulation of the demand diversity for each hamlet

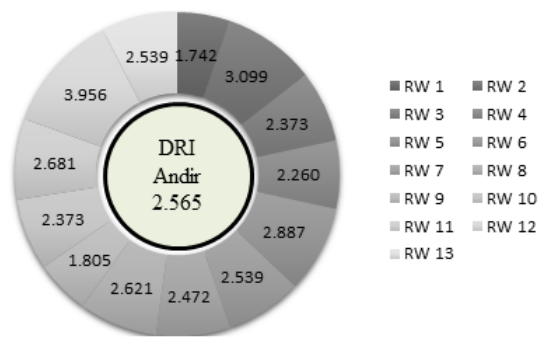

Figure 5. Recapitulation of DRI values for the study area of Andir Urban Village

\section{Conclusions and recommendations}

Andir Urban Village has a low Flood Resilience Index (FRI) of 2.69 (out of 5). Green open space is the indicator with the lowest FRI of 0.45 . Meanwhile, the Drought Resilience Index is only 2.565 out of 10 . Hamlet 1 has the lowest Drought Resilience Index of 1.742 out of 10 . Green open space needs to be added in the study area which can also act as a buffer area. This should be further supported by the Sustainable Urban Drainage Systems which can help improve drainage conditions in the Cisangkuy-Citarum watershed. Furthermore, a collaboration between the community and the government is needed in order to effectively form a region that is resilient to flooding. This can be via operative river conservation programs and information dissemination as a means of capacity building in the community.

From this study, it is evident that the measurements of Flood Resilience Index and Drought Resilience Index in Indonesia, a developing country, needs to be done carefully by developing local indicators that are unique, relevant, and important to the country's setting. Formal guidelines pertaining to this need to be developed in order to make sure that the measurements are applicable and comparable throughout the country. Only through these efforts, results from the measurements can be meaningful and useful in improving community and regional resilience in Indonesia. After all, a country's resilience is dependent upon its community and regional resiliencies.

This study did not discuss the effectiveness of the programs and the solutions in reducing the effects of flooding for the community in the study area. This can be used as input for future research.

This research was supported by the Institut Teknologi Bandung (ITB) Riset Unggulan research program to the Research Center for Infrastructure and Regional Development (RCIRD). The views, opinions, and findings contained in this paper are those of the authors and should not be construed as an official ITB or Indonesian government position, policy, or decision. The authors declare no conflict of interest. The questionnare data used during this study are available from the corresponding author by request.

\section{References}

1. I. Goklany, Death and death rates due to extreme weather events (International Policy Network, London, 2007)

2. S. Stolton, N. Dudley, J. Randall, Arguments for protection- natural security protected areas and hazard mitigation (World Wide Fund for Nature, 2008)

3. BNPB, http://bnpb.cloud/dibi/ (2019)

4. Asian Development Bank, Asian water development outlook 2016: Strengthening water security in Asia and the Pacific (ADB, 2016)

5. V.S. Kale, Singapore Journal of Tropical Geography, 35, 161 (2014)

6. A.K. Jha, R. Bloch, J. Lamond, Cities and flooding: a guide to integrated urban flood risk management for the 21st century (World Bank Publications, 2012)

7. J. J. Messakh, A. Sabar, I.K. Hadihardaja, Z. Dupe, International Journal of Scientific \& Engineering Research, 6 (2015)

8. T. Cannon, Disasters, development and the environment (John Wiley, 1994)

9. W.N. Adger, T. Hughes, C. Folke, S.R. Carpenter, J. Rockström, Science 309, 1036 (2005)

10. B. Walker, C.S. Holling, S.R. Carpenter, A. Kinzig, Ecology and Society 9, 5 (2004)

11. J. Batica, P. Gourbesville, F. Hu, Proceedings of International Conference on Flood Resilience Experiences in Asia and Europe (ICFR, Exeter, 2013)

12.P. Gonzalez, K.A. Newsha, Sustainable Cities and Society 30, 128 (2017)

13. C. Zevenbergen, W. Veerbeek, B. Gersonius, S. Van Herk, Journal of Flood Risk Management 1, 81 (2008)

14. Bandung Regency Statistical Agency, Kecamatan Baleendah Daam Angka Tahun 2016 (Badan Pusat Statistik Kabupaten Bandung, 2016)

15. R.B. Burns, R.A. Burns, Business Research Methods and Statistics Using SPSS (Sage Publications, 2008)

16. J. Batica, Methodology for flood resilience assessment in urban environments and mitigation strategy development (Universite Nice Sophia Antipolis, 2015) 